\section{Lysimachia congestiflora 'Zidie': An Ornamental Plant with Fancy Leaves}

\author{
Wei Zheng, Xiu-Qun Liu, and Longqing Chen ${ }^{1}$ \\ Huazhong Agricultural University, College of Horticulture and Forestry \\ Services, Shizishan Street, Hongshan, Wuhan, Hubei Province 430070, \\ China
}

Additional index words. dense-flowered loosestrife, wild variation, plant introduction, groundcover

The genus of Lysimachia L. contains 191 species (Takhtajan, 1997), and the majority of Lysimachia species occur throughout temperate and subtropical regions of the Northern Hemisphere (Chen and Hu, 1989). In China, more than 50 Lysimachia species are exploited as medicinal herbs (Zheng et al., 2009a). Apart from their medicinal value, the Lysimachia plants have ornamental significance. At present, $\approx 30$ Lysimachia cultivars are used as commercial landscape plants (Zheng et al., 2009b).

Dense-flowered loosestrife (L. congestiflora Hemsl.), a mat-forming herbaceous perennial, is widely distributed in south, southwest, and central China with a subtropical continental monsoon climate (Chen and $\mathrm{Hu}, 1989$ ). Thanks to the highly ornamental merit of the species, now approximately nine cultivars (especially those with colorful foliage) have been traded as groundcover or hanging basket plants in northern America and Europe. The showy foliage and yellow flowers also lend potential for using the cultivars in year-round production as potted plants as a result of the environmental control research of flowering and growth of the species (Zhang et al., 1995).

Although the wild-type $L$. congestiflora usually has green foliage, some variations with colorful foliage in the wild are valuable to be exploited. This article reports a new colorful foliage cultivar selected from wild variations in $L$. congestiflora.

\section{Origin}

A new color-leaf variation of $L$. congestiflora was discovered by W. Zheng and L.Q. Chen at the Three Gorges (Dazhou County, Sichuan Province, China) and introduced to the nursery of Huazhong Agricultural University in 2006. In the interest of the commercial value, the plant was sent to university cooperators (Huangshi and Xianning Nursery) for further evaluation in Hubei Province

Received for publication 28 May 2009. Accepted for publication 21 July 2009.

${ }^{1}$ To whom reprint request should be addressed; e-mail chenlq0206@163.com. in 2007. After evaluating for 3 years, the cultivar was named 'Zidie' (purple butterfly in Chinese) in accordance with the International Code of Nomenclature for Cultivated Plants (Brickell et al., 2004). Its voucher specimen (Zheng and Chen 0802) is deposited in the Botanical Herbarium of Huazhong Agricultural University.

\section{Description}

Descriptions of the plant color are based on the Royal Horticulture Society Color Chart [Royal Horticulture Society (RHS), 1986]. The described plants were grown in full sun under common cultivation.

L. congestiflora 'Zidie' has a uniform, creeping growth habit with 5 to $15 \mathrm{~cm}$ of canopy thickness. Dark purple-red (RHS 185B) stems are 10 to $40 \mathrm{~cm}$ long with ascending branches and roots at basal nodes. The surface of stems and leaves have some white (RHS 157B) articulate hairs. Leaves are ovate or cordiform, opposite, up to $2.4 \mathrm{~cm}$ long $\times 1.8 \mathrm{~cm}$ wide. The two pairs of upper leaves (like purple butterflies; Fig. 1) are always dense with dark purple-red (RHS 185B) interveinal areas and green (RHS 139C) venations. The colors of interveinal areas of the lower leaves change toward the basal leaves from purple-brown (RHS 183A), brown (RHS N199C), brown-green (RHS 152B) to green (RHS 137C). Flowering occurs in late spring and lasts $\approx 30 \mathrm{~d}$. The peak flowering stage appears in May with $3008 \pm 35.58$ flowers $/ \mathrm{m}^{2}$. The raceme is

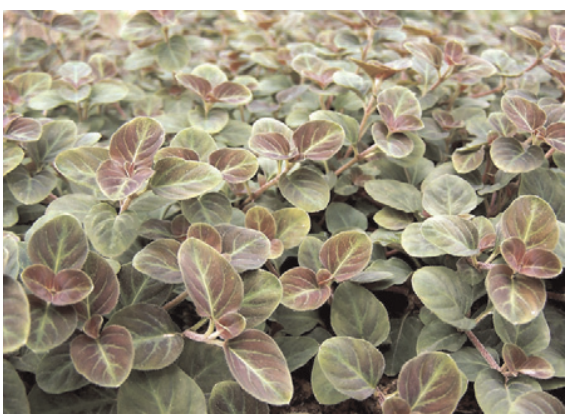

Fig. 1. Lysimachia congestiflora 'Zidie' used as groundcover. constituted by three to eight flowers. The yellow (RHS 13B) flower is bell-shaped, upturned, and shoots out from the stem terminal (Fig. 2). Flower diameter is 1.4 to $1.6 \mathrm{~cm}$, corolla tube is 2 to $3 \mathrm{~mm}$ in length, petals elliptic, up to $1.2 \mathrm{~cm}$ long, and $0.5 \mathrm{~cm}$ wide. With the comparison with the flower of its wild-type, 'Zidie' has no red corolla base. Additionally, 'Zidie' has few seeds as a result of a quite low seed-setting rate $(1.0 \%)$.

\section{Performance}

The performance of Lysimachia congestiflora 'Zidie' in different shade was evaluated in the nursery of Huazhong Agricultural University. Growth trial was initiated using three-node terminal cuttings. Each 50 cuttings were grown under $75 \%, 47 \%, 22 \%$, and $0 \%$ shade, respectively, using a completely randomized design. Light was limited by covering the outdoor plots with voile net or black woven shadecloth. The experiment was conducted under common management with average soil of moderate fertility and a temperature range of 10 to $32{ }^{\circ} \mathrm{C}$. Seventyfive days (from 20 Mar. to 5 May 2008) later, the recorded data included the number of branches, leaves and flowers, average length of main stem and internodes, mulch area, and shoot dry weight per plant.

The plants were grown in the field $\left(50 \mathrm{~m}^{2}\right)$ with routine cultivation from 2006 to 2008 for additional evaluations, including disease and pest susceptibility, reseeding or invasiveness, flooding tolerance in the rainy season, heat tolerance in summer (average temperature of $29.6{ }^{\circ} \mathrm{C}$, maximum temperature of $39.2{ }^{\circ} \mathrm{C}$ in July), and freezing tolerance in winter (average temperature of $2.2{ }^{\circ} \mathrm{C}$, minimum temperature of $-5.3{ }^{\circ} \mathrm{C}$ in January). The performance was evaluated by the proportion of vigorous leaves and visual quality ratings (number " 1 ," " 3 ," or " 5 " for poor, acceptable, or excellent quality, respectively). L. nummunaria 'Aurea' was used as a control plant. All data were analyzed using analysis of variance and Duncan's multiple range tests.

'Zidie' grew well in different shade. Average values of leaf area, internode length, and main stem length increased with crescent shade (Table 1), whereas the numbers of leaves and flowers and shoot dry weight

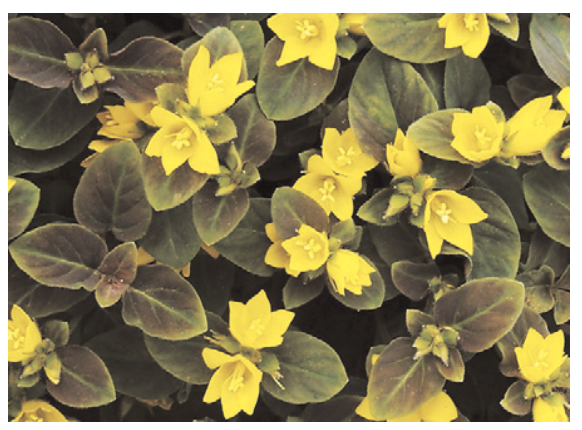

Fig. 2. Lysimachia congestiflora 'Zidie' with flowers in May. 
Table 1. Performance of Lysimachia congestiflora 'Zidie' in different shade.

\begin{tabular}{|c|c|c|c|c|c|c|c|c|}
\hline $\begin{array}{l}\text { Shade } \\
(\%)\end{array}$ & $\begin{array}{l}\text { Avg. length } \\
\text { of internodes } \\
(\mathrm{cm})\end{array}$ & $\begin{array}{c}\text { Avg. area } \\
\text { of leaves } \\
\left(\mathrm{cm}^{2}\right)\end{array}$ & $\begin{array}{l}\text { Avg. length } \\
\text { of main stem } \\
(\mathrm{cm})\end{array}$ & $\begin{array}{c}\text { No. of } \\
\text { branches }\end{array}$ & $\begin{array}{l}\text { No. of } \\
\text { leaves }\end{array}$ & $\begin{array}{l}\text { No. of } \\
\text { flowers }\end{array}$ & $\begin{array}{c}\text { Shoot } \\
\text { dry wt (g) }\end{array}$ & $\begin{array}{c}\text { Mulch } \\
\text { area }\left(\mathrm{m}^{2}\right)\end{array}$ \\
\hline 0 & $2.47^{z}$ & $4.49 \mathrm{c}$ & $27.93 \mathrm{~b}$ & 68.67 & $356.67 \mathrm{a}$ & $22.47 \mathrm{a}$ & $4.31 \mathrm{a}$ & 0.62 \\
\hline 22 & 2.54 & $5.35 \mathrm{bc}$ & $28.21 \mathrm{~b}$ & 71.67 & $302.00 \mathrm{~b}$ & $23.64 \mathrm{a}$ & $3.78 \mathrm{~b}$ & 0.56 \\
\hline 47 & 2.75 & $6.16 \mathrm{~b}$ & $35.80 \mathrm{a}$ & 70.67 & $296.00 \mathrm{~b}$ & $18.57 \mathrm{~b}$ & $3.35 \mathrm{~b}$ & 0.61 \\
\hline 75 & 2.86 & $7.29 \mathrm{a}$ & $34.83 \mathrm{a}$ & 66.67 & $278.67 \mathrm{c}$ & $16.93 \mathrm{~b}$ & $2.86 \mathrm{c}$ & 0.60 \\
\hline
\end{tabular}

${ }^{\mathrm{z}}$ Means in a column followed by the same letter do not differ significantly at $P<0.05$.

Table 2. Performance of Lysimachia congestiflora 'Zidie' in hot summer and freezing winter. ${ }^{z}$

\begin{tabular}{|c|c|c|c|c|}
\hline \multirow[b]{2}{*}{ Cultivar } & \multicolumn{2}{|c|}{ Vigorous leaves (\%) } & \multicolumn{2}{|c|}{ Quality $^{\mathrm{y}}$} \\
\hline & Summer & Winter & Summer & Winter \\
\hline L. nummunaria Aurea & $26.32 b^{x}$ & $4.23 \mathrm{~b}$ & $1.35 \mathrm{~b}$ & 1.86 \\
\hline L. congestiflora Zidie & $92.66 \mathrm{a}$ & $21.38 \mathrm{a}$ & $4.78 \mathrm{a}$ & 2.13 \\
\hline
\end{tabular}

${ }^{\mathrm{z}}$ Value presented are means of five replications with $1 \mathrm{~m}^{2}$ of plants per year averaged over 3 years $(2006$ to 2008).

${ }^{y}$ Visual rating where 1 = poor, 3 = acceptable, $5=$ excellent quality.

'Means separation within columns by Duncan's multiple range tests $(P<5 \%)$.

decreased with increasing shades. The numbers of branches $\left(R^{2}=0.17\right)$ and mulch area $\left(R^{2}=0.01\right)$ showed no obvious difference among these shades (Table 1). The result indicated that $L$. congestiflora 'Zidie' was adaptable to light intensity. Therefore, it can be planted under full sun or partial shade.

Shade affected leaf color of 'Zidie'. The two pairs of upper leaves had dark purple-red (RHS 185B) interveinal area in full sun, whereas they were dark purple-brown (RHS $187 \mathrm{~A}$ ) under $75 \%$ shade. Thus, full sun is better for bright leaf color of 'Zidie' and the best ornamental quality.

The 'Zidie' can adapt the stress conditions of a torrid summer and freezing winter. Based on Duncan's multiple range tests (Table 2), the proportions of vigorous leaves and quality of Lysimachia congestiflora 'Zidie' were significantly higher than those of $L$. nummunaria 'Aurea' in the summer, which indicated that heat tolerance of 'Zidie' was stronger than that of 'Aurea'. In freezing temperature, the proportion of vigorous leaves of 'Zidie' was significantly greater than that of 'Aurea', but there was no difference among these two plants in ornamental quality (Table 2). Although the leaves on the stem base were injured by continuous snow cover for $30 \mathrm{~d}$ in Jan. 2008 (Fu et al., 2008), plants resumed growth quickly in the new early spring. Thus, 'Zidie' exhibited strong heat and freezing tolerance.

During the experimental years, few seeds germinated in the field and no clones migrated. In the second-year plantings, vegetative propagates spread around but there was little invasiveness. The basal leaves of 'Zixin' yellowed partially when the whole plants were flooded for $3 \mathrm{~d}$, yet the plants remained vigorous and resumed to grow immediately after flooding. 'Zidie' plants were free of major diseases and suitable for the soil with moderate fertility. Furthermore, 'Zidie' is readily propagated by cutting because the data indicated that $99 \%$ of cuttings rooted easily from basal nodes within 1 week.

In a word, the pretty good performance will render this new cultivar an excellent choice for urban landscaping in central China as well as other similar climatic regions.

\section{Availability}

Lysimachia congestiflora 'Zidie' will be trademarked and is intended for groundcovers, hanging baskets, or potted plants. A patent application has been submitted to the Patent Office of Hubei Province, China. The plant patent rights will be assigned to Huazhong Agricultural University. Inquiries regarding 'Zidie' can be obtained by sending e-mail to chenlq0206@163.com. Plants for research purposes may be obtained directly from the author.

\section{Literature Cited}

Brickell, C.D., B.R. Baum, W.L.A. Hetterscheid, A.C. Leslie, J. McNeill, P. Trehane, F. Vrugtman, and J.H. Wiersema. 2004. International code of nomenclature for cultivated plants 7 th ed. Acta Hort. 647:1-84.

Chen, F.H. and C.M. Hu. 1989. Flora of China. $59: 1-160$

Fu, J.J., S.L. Li, and Y.M. Wang. 2008. Influence of prior thermal state of global oceans on the formation of the disastrous snow storm in Jan. 2008. Clim. Environ. Res. 13:478-490.

Royal Horticulture Society. 1986. RHS colour chart. Royal Hort. Soc., London, UK.

Takhtajan, A.L. 1997. Diversity and classification of flowering plants. Columbia University Press, New York, NY.

Zhang, D., A.M. Armitage, J.M. Affolter, and M.A. Dirr. 1995. Environmental control of flowering and growth of Lysimachia congestiflora Hemsl. HortScience 30:62-64.

Zheng, W., X.D. Xu, H. Dai, and L.Q. Chen. 2009a. Direct regeneration of plants derived from in vitro cultured shoot tips and leaves of three Lysimachia species. Sci. Hort. 122:138141 .

Zheng, W., X.D. Xu, K.G. Zhao, and L.Q. Chen. 2009b. Lysimachia christinae 'Zixin': A new groundcover plant. HortScience 44:474-475. 